\title{
Coding and data analysis during qualitative empirical research in Practical Theology
}

\begin{abstract}
Author:
Petria M. Theron ${ }^{1}$

Affiliation:

${ }^{1}$ Faculty of Theology, School of Biblical Counselling and Church Ministry, North-West University, Potchefstroom Campus, South Africa

Correspondence to:

Petria Theron

Email:

petria.theron@nwu.ac.za

Postal address:

Bali Hoff 07, Pezcod Street,

Potchefstroom 2531,

South Africa

Dates:

Received: 10 Sept. 2014

Accepted: 07 Sept. 2015

Published: 13 Nov. 2015

How to cite this article:

Theron, P.M., 2015, 'Coding

and data analysis during

qualitative empirical research

in Practical Theology', In die

Skriflig 49(3), Art. \#1880,

9 pages. http://dx.doi.

org/10.4102/ids.v49i3.1880

\section{Copyright:}

(C) 2015. The Authors.

Licensee: AOSIS

OpenJournals. This work is

licensed under the Creative

Commons Attribution

License.
\end{abstract}

Read online:
I dedicate this article to Prof. George Lotter, who has been instrumental in the formation of more than 90 postgraduate students in practical theological studies at the North-West University (NWU). Under his guidance, a significant amount of empirical research has been conducted. This is in line with a movement among scholars, both national and international, towards a more empirical approach in Practical Theology. It is therefore indispensable that both lecturers and students in Practical Theology should further develop their empirical research capacities. In this article, it is argued for a more systematic approach during the coding and data analysis phase of qualitative research and the article concludes with a proposed model for coding and data analysis in practical theological studies.

Kodering en data-analise tydens kwalitatiewe empiriese navorsing in Praktiese Teologie. Hierdie artikel word aan prof. George Lotter opgedra. Deur die jare was hy instrumenteel in die vorming van meer as 90 nagraadse studente in Praktiese Teologie by die Noord-Wes Universiteit (NWU). Baie empiriese navorsing het onder sy leiding plaasgevind. Dit is in ooreenstemming met die nasionale en internasionale tendens van 'n meer empiriese benadering in Praktiese Teologie. Dit is dus van die uiterste belang dat Praktiese Teologie-dosente en -studente se vaardighede in empiriese navorsing verder ontwikkel moet word. In hierdie artikel word aangetoon dat 'n meer sistematiese benadering gevolg moet word tydens die kodering en die data-analisefase van kwalitatiewe navorsing. ' $n$ Model vir die kodering en data-analise vir navorsing in Praktiese Teologie word ook voorgestel.

\section{Introduction}

The broad theme of this edition of In die Skriflig/In Luce Verbi in honour of Prof. George Adrian Lotter is 'Pastoral Theology in SA: Semper reformanda'. The Latin phrase semper reformanda means 'always reforming' and it has become a widely known motto of the reformed tradition (Troxel 2006). It first appeared in 1674 in a devotional by Van Lodenstein, an important figure in a movement known as the Dutch Second Reformation (Horton 2014). The phrase is often used and even misused as a motivation or justification for change, for example that churches should be more open to move beyond the faith and practice they confess in their doctrinal standards and allow innovation. However, Troxel (2006) and Horton (2014) make a strong appeal that one should use the phrase according to its true meaning of 'always being reformed or changed ${ }^{1}$ in accordance with Scripture and the Lordship of Jesus Christ. ${ }^{2}$ The doctrine of the church was reformed during the Reformation, but in the 21st century the lives and practices of God's people need further reformation. Wolters (1992:1) stresses the point that incessant reformation should conform to the Word of God (Rm 12:2) and not, as Horton (2014) warns, to the spirit of the age.

I have come to know George Lotter not only as a person who is willing to change according to the Word of God, but also as somebody who is open to change, new ideas and new ways of doing things in practising his subject, pastoral studies. However, he does not approach change in an uncritical manner, but evaluates it against the truths of God's Word. To me, he personifies somebody who is faithful to the reformational principal of semper reformanda. The choice of the title of his article on how secular psychology has taken over the field of traditional biblical counselling during the 19th and 20th centuries, and how Jay Adams has done pioneer work to regain the ground, is significant, namely The 'reformation' of counselling. Lotter (2001:328) demonstrates how the motto semper reformanda can be put into practice in academic endeavours, especially in pastoral theology and biblical counselling. Although Lotter worked and still works in the

1.The Oxford's translation of the Latin phrase semper reformanda is given as 'always to be reformed' (Bowker 1999:874).

2.Sola Scriptura and Solus Christus are two of the five well-known reformational principles (Vorster 2010:432). 
field of Pastoral Theology, justifying the choice of the theme of this edition of In die Skriflig/In Luce Verbi in his honour, I choose to write this article in the broader domain of Practical Theology as will also become evident in the research results later. I therefore deem it necessary to briefly situate Pastoral Theology within the broader domain of Practical Theology.

In the time of modernity, Practical Theology was restricted to the application of doctrine in pastoral situations, but from 1950 onwards, scholars in theology and religion have challenged this point of view (Miller-McLemore 2012:1). One can speak of a revival of Practical Theology during the early 1980s when the need for practical knowledge became evident. Researchers like Browning, Poling, Miller, Forrester and Dykstra in the United States, Ballard and Pritchard in England and Van der Ven from the Netherlands, among others, responded by viewing the role of Practical Theology anew (Miller-McLemore 2012:2-3). In the process, it became clear that it is not easy to define Practical Theology. It is a multivalent discipline found in a wide range of spaces and places. Miller-McLemore (2012) gives the following definition in terms of four distinct enterprises, different audiences and different objectives:

Practical Theology is an activity of believers seeking to sustain a life of reflective faith in the everyday, a method or way of understanding or analysing theology in practice used by religious leaders and by teachers and students across the theological curriculum, a curricular area in theological education focused on ministerial practice and sub-specialities, and an academic discipline pursued by a smaller subset of scholars to support and sustain these first three enterprises. (p. 5)

Dreyer (2012:511), writing from a South African perspective, agrees with Miller-McLemore that Practical Theology can no longer be seen as only studying pastoral actions, actions related to church life or the training of pastors. An 'outward' movement is also visible in South Africa as practical theologians are increasingly involved in societal, political and economic issues. The themes of the past three annual meetings of the Society of Practical Theology in South Africa, namely Practical Theology and service delivery (2013), Practical Theology in Africa and human waste (2014), and The power of religion and religions of power within African contexts (2015) demonstrate it.

Coming back to the relationship between Pastoral Theology and Practical Theology, Miller-McLemore (2012:6) sees the former as both person- and pathos-centred with the focus on care. In his inaugural address, Lotter (2007:2) also emphasises the aspect of care by referring to the biblical foundation of Pastoral Theology, namely the metaphors and the parables of the pastor and his sheep, where the pastor is intensely involved with each one of his sheep (Ps 23; Ezk 34; Jn 10). Practical Theology, according to Miller-McLemore (2012:6), is more concerned with integrating knowledge within theological education and mediating interaction between the seminary, the congregation and the wider society. Dreyer (2012:513), McClure (2012:269) and De Klerk and De Wet (2013:x) offer an alternative way to view the relationship, namely that Pastoral Theology is one of the sub-disciplines of Practical Theology.

The title of this article indicates that the focus will be on empirical research within the discipline of Practical Theology. Dingemans (1996:87) refers to the shift that has taken place in the last decades of the previous century, namely investigating Christian practice instead of merely applying biblical data and statements of faith. Five years earlier, Pieterse (1991:6) also wrote about this movement to emphasise empirical research in Practical Theology. He referred to Bastian who strongly argued in 1968 that Practical Theology should take theory and praxis into consideration and that the actions and activities of the church should be analysed empirically. In 1974, states Pieterse (1991:7), Zerfass focused on the actions of the church and his cyclic model for the theory-praxis-reflection has become well known. Practical theologians at the North-West University (NWU) have followed this model for many years. Until the 1980s, practical theologians worldwide made use of empirical insights from the social sciences (Dingemans 1996:87; Dreyer 2012:512). However, at the beginning of the 1990s, Van der Ven sets forth a proposal for an empirical approach to Practical Theology so that practical theologians can generate their own data by investigating the ecclesiological praxis. He refers to empirical theology (Burger 1991:15; Dreyer 2012:513; Van der Ven 1993:vii). If one looks at the list of publications by practical theologians like Pieterse and Dreyer from UNISA (University of South Africa), this movement towards a more empirical approach to Practical Theology is also visible in South Africa (Dreyer 2015; Pieterse 2010, 2011, 2012, 2013, 2015). However, I wholeheartedly agree with Dreyer (2012:513) that lecturers and students should develop their empirical research capacities further.

My central theoretical argument in this article is that postgraduate practical theological studies and research articles may greatly benefit from the use of a more systematic approach during the coding and data analysis phase of qualitative empirical research. In this article, I first offer an overview of recent empirical research done by practical theologians and postgraduate students at the NWU. Then I focus on coding as an important part of data analysis during qualitative empirical research. I also present different approaches to data analysis in qualitative research. In conclusion, I propose a model for coding and data analysis during qualitative empirical research in practical theological studies.

\section{Empirical research in Practical Theology at North-West University}

In this section, I will give an overview of the recent use of empirical research by practical theologians at the Faculty of Theology at the NWU. I will limit the scope of the research to postgraduate studies done between 2010 and 2013 and articles published in accredited scientific journals by lecturers, postdoctoral fellows and associates in the field of Practical Theology during the same time. The investigation 
will provide quantitative data, reporting on how many of the researchers made use of empirical methods, and qualitative data, analysing the empirical methods the researchers used in their research.

\section{Quantitative data}

At every graduation ceremony of the NWU, the list of students who receive a degree at the particular graduation ceremony is printed in a booklet. These booklets are available at the office of the manager of the $\mathrm{M}$ and $\mathrm{D}$ programmes at the Faculty of Theology. I have consulted the booklets of 2010 to 2013 and found that 17 masters and 21 doctoral studies were completed in the field of Practical Theology. By looking at the content of each of these studies, I noticed that 37 of these 38 postgraduate studies made use of empirical research. That is a percentage of $97.4 \%$.

In order to identify all the practical theological research articles published in accredited scientific journals by lecturers, postdoctoral fellows and associates of the Faculty of Theology, I consulted the reports of the research director for the years 2010 until 2013. Surveying these reports, I determined that 94 articles were published during these years. Of these 94 articles, only 22 made use of empirical research. That is a percentage of $23.4 \%$.

\section{Qualitative data}

For the purpose of this article, it is important to analyse the empirical methods that were implemented in the postgraduate studies and articles mentioned above.

The following empirical methods were used in the 37 postgraduate studies:

- In four studies, only quantitative methods were used. Three of the researchers developed a questionnaire for the purpose of their studies. They distributed it among their participants and evaluated the results statistically. One researcher used an existing inventory and made deductions from the results.

- In 25 studies, only qualitative methods were used. Most of the researchers developed a questionnaire for the purpose of their studies. They distributed it among their participants and followed it up with semistructured interviews, based on the questionnaire, to ensure that they obtained all possible information from the participants. The majority of the researchers then categorised the data according to emerging themes and made deductions from the results. They did not indicate how the categories or themes were established. One of the researchers used an existing inventory, conducted semi-structured interviews based on the inventory and made deductions from the data. One researcher made use of case studies by analysing sermons and making deductions from the results. Another researcher used case studies of semi-structured counselling sessions and made deductions from it. One researcher used the Delphi method of research.
- In eight studies, the researchers used a combination of quantitative and qualitative methods. They either used an existing inventory or developed a questionnaire themselves to examine the phenomenon. They interpreted the results statistically and then followed the investigation up by a questionnaire, and/or a semi-structured interview, and/or counselling sessions. Subsequently, they made deductions from the data. In one case, the researcher repeated the use of the existing inventory to investigate the effectiveness of the counselling sessions.

In the 22 research articles, I distinguished the following empirical methods:

- In two articles, the quantitative method was used and deductions were made from the results.

- In three articles, the researchers used a mixed method. They made use of a questionnaire to obtain quantitative data. In order to obtain the qualitative data, they asked the participants to give their comments in the form of a report. They coded the unstructured data by identifying categories without indicating which coding method they used to establish the categories. They then used the categories to develop a second questionnaire. The results of the second questionnaire confirmed the results of the first questionnaire and the reports. From the results, they made certain deductions.

- In two articles, the researchers made use of case studies to illustrate the issue under discussion, after which the researchers made deductions.

- In one article, the researcher used a semi-structured questionnaire to compile case studies, from which deductions were made.

- In two articles, the researchers used auto-ethnography and made deductions from the narratives.

- In one article, the researcher used an online survey to investigate the specific phenomenon. The survey also included a narrative section where the participants could share further comments. Deductions followed from the data.

- In one article, the researcher demonstrated the Delphi survey method in a practical theological research endeavour.

- Ten researchers used the following qualitative method of research: They developed a questionnaire with openended questions, gave it to a few participants to complete, followed it up by an interview to ensure a response to all the questions and then analysed the data. Seven of the researchers analysed the data by simply identifying recurring themes and then making deductions from it. In three articles, the researchers used the eight steps of Tesch to categorise the data in themes and subthemes. They then made their deductions.

\section{Discussion of the results}

A high percentage of postgraduate students included empirical research as part of their studies, whilst less than a quarter of the articles in accredited journals included empirical research. Most of the articles in which empirical 
research is reported are articles published by postgraduate students and their study leaders, as part of the postgraduate studies. The rest of the articles where empirical research are included, are by postdoctoral fellows and associates. From the results of this investigation, it is clear that the Practical Theology lecturers of the NWU do not often embark on empirical research in their own research, although they expect it from their postgraduate students.

If one considers the empirical methods implemented, it is evident that most of the researchers used qualitative methods. The method most frequently used entails the following. The researchers developed a questionnaire according to the theme of the particular study and asked their participants to complete it. After the questionnaire, they often had semistructured interviews with the participants in order to ensure that all possible information was obtained. The researchers then made conclusions based on the data. I encountered only a few researchers who mentioned that they coded and categorised the data according to emerging themes. They seldom mentioned the methodology they used during the coding process. Only three researchers mentioned in their articles that they followed the eight steps of Tesch to categorise their data in themes and subthemes. One gets the idea that when these researchers do coding, they do it intuitively.

One can wonder about the 'truth value' of the qualitative research projects. Schurink, Fouché and De Vos (2012:419) refer to the traditional criteria for good qualitative research, namely internal and external validity, reliability and objectivity, but qualitative researchers Lincoln and Guma propose that credibility, transferability, dependability and conformability are better indicators of good qualitative research. Of these four criteria, they consider credibility to be the most important one. Credibility refers inter alia to the fact that researchers portray accurately what the participants conveyed. One way to increase this is by means of member checks (2012:420). I am of the opinion that the implementation of thorough coding and data analysis will significantly contribute to improve the credibility of the qualitative empirical research of practical theologians at the NWU. This is the focus of the rest of the article.

\section{Coding: An important part of data analysis}

Smith and Davies (2010:155) argue that coding does not constitute the totality of data analysis, but it is a method to organise the data so that underlying messages portrayed by the data may become clearer to the researcher. Charmaz (2006:46) describes coding as the pivotal link between data collection and explaining the meaning of the data. A code is a descriptive construct designed by the researcher to capture the primary content or essence of the data. Coding is an interpretive activity and therefore it is possible that two researchers will attribute two different codes to the same data. The context in which the research is done, the nature of the research and the personality and interest of the researcher will influence which codes the researcher attributes to the data (Engler 2014:257; Saldaña 2013:3-4, 8). During the coding process, some codes may appear repeatedly and that may be an indication of emerging patterns. These emerging patterns or similarity among the codes may give rise to categories. Coding is not only labelling, but also linking, that is, linking data to an idea. It is a cyclic process. By incorporating more cycles into the coding process, richer meanings, categories, themes and concepts can be generated from the data (Saldaña 2013:5, 8).

\section{Practical aspects of coding}

Saldaña (2013:17) gives practical advice for the coding process. He says that it is helpful to type the data on the left two-thirds of a page and to leave the right margin open for notes. Whenever the topic of the data seems to change, the researchers can start a new paragraph. In writing down the data, researchers need to decide whether they want to give a verbatim transcription of the interviews for their specific study. It is the opinion of Smith and Davies (2010:149) that it is not always necessary and that the essence (gist) of the interview is sometimes sufficient. Whilst reading the data, states Saldaña (2010:19-20), the researcher can do some 'precoding' by circling, highlighting or underlining significant words or sentences. However, the author urges researchers to start the coding process whilst they are collecting the data, keeping in mind that the codes may change during later cycles. Saldaña (2010:21-22) suggests that researchers should keep their research questions and aims of their studies in mind. The following questions may assist them in their coding decisions:

- What are people doing? What are they trying to accomplish?

- Exactly how are they doing it? What strategies are they using?

- How do they talk about, characterise and understand what is going on?

- What assumptions are they making?

- What is going on here? What do I, as researcher, learn from these notes? What strikes me?

These questions correspond with aspects, mentioned by Gibbs (quoted in Smith \& Davies 2010:153), that may be coded, namely activities or behaviour, events, strategies or tactics, present situations, meanings, participation, relationships or interactions, conditions or constraints, consequences, settings and the researcher's own reflections.

The number of codes, Saldaña (2013:22-24) states, depends on the context, the nature of the data and to what degree of fineness the researcher wants to examine the detail. Data can be 'lumped' together with a single code or can be 'split' into many smaller parts, each bearing its own code. Both methods have advantages and disadvantages. Even though splitting is time-consuming, it may produce a more nuanced analysis. On the other hand, lumping gets to the essence of categorising, although it may produce superficial analysis. The number of codes may change during a second cycle of 
coding. Saldaña $(2013: 26,28)$ advises that the initial coding should be done on hard copies, although electronic resources are available, as hard copies tend to give a better perspective. Coding is usually a solitary act, but he (2013:34-35) advises that researchers should share their coding and analysis with colleagues or even the participants as a way of validating the findings and enriching the analysis.

\section{Writing analytic memos: Concurrently with coding}

The analytic memos document how the coding process is developing and codes may trigger deeper reflection on the side of the researcher on the meaning of the data. It is important that researchers write down their insights (Saldaña 2013:41-42). Analytical memos give researchers the opportunity to reflect and comment on the following:

- how they personally relate to the participants and the phenomenon;

- their research questions;

- the code choices;

- emergent patterns and categories;

- problems and ethical dilemmas in the study; and

- the future direction for the study.

Writing analytical memos can be seen as the transitional phase from coding to the more formal writing of the report on the study. The analytical memos can also be coded and categorised and may even lead to better codes or categories for the data (Saldaña 2013:49-51).

\section{Useful coding methods for Practical Theology}

Saldaña (2013:51) mentions that grounded theory, one of the approaches in qualitative research, has six coding techniques in its coding canon. Researchers normally use these coding methods during two coding cycles. During the first cycle, the data is split into segments and in vivo coding, process coding and initial coding may be used. During the second cycle, researchers compare codes, note emerging patterns and reorganise the data into categories by using the focused, axial and theoretical coding techniques. More detail on each of the six coding techniques follow, but it is important to note that researchers can use these coding methods also in nongrounded theory studies (Saldaña 2013:51).

\section{In vivo coding}

This method of coding is useful for beginner qualitative researchers, as the exact word or phrase of the participant serves as a code. In order to distinguish in vivo codes, the researchers put them between inverted commas. The researchers look for words or phrases that seem to stand out, for example nouns with impact, action-orientated verbs, evocative word choices, clever phrases or metaphors. In vivo coding can be the only coding method used during the first cycle of data analysis, but it may be limiting. Sometimes the participant says something in the best way and other times the researchers do it better. The following phrases serve as examples of in vivo codes: 'freshman year awful', 'found stuff out', 'wasn't trying so hard' and 'friends got closer' (Saldaña 2013:91-94).

\section{Process (action) coding}

A process code is a word or a phrase that captures action. It is done by using gerunds ('-ing' words) as part of the code. Process coding is useful to identify an on-going action as a response to situations, or an action to handle a problem, or to reach a goal. As a process code usually conveys movement and shows how things have changed over time, it helps the researchers to give a dynamic account of events. It conveys a trail of the participant's process, for example: criticising rumours; not caring what people think; finding out who your real friends are (Saldaña 2013:5, 96-99).

\section{Initial (open) coding}

Initial coding refers to the process of breaking the qualitative data down into distinct parts and coding these by using in vivo coding, process coding, and other coding methods. The researchers then examine these parts closely and compare them for similarities and differences. During this process, the researchers may already become aware of emerging categories and code them. It is important to remember that these initial codes and categories are tentative and may change as the analysis process progresses. After initial coding, the researchers need time for reflection by means of the writing of analytical memos (Saldaña 2013:100-101).

\section{Focused coding}

Saldaña (2013:213) explains that after initial coding, the researchers embark on focused coding by identifying the most frequent or significant codes in order to develop the prominent categories (it is linked to axial coding). He warns that the researchers should be aware that these categories do not always have well-defined boundaries and that the codes in a specific category may have different degrees of belonging. Rubin and Rubin (quoted by Saldaña 2013:216) recommend that the researchers organise the categories hierarchically in main categories and subcategories in order to understand the relationship between them.

\section{Axial coding}

The goal of axial coding is the strategic reassembling of data that have been split during initial coding. In the process of crossing out synonyms and redundant codes, the dominant codes will become apparent. The axis of the axial coding is a category. During axial coding, categories are related to subcategories and the properties and dimensions of a category are specified (Saldaña 2013:218). Central categories describe the key properties of the phenomenon, causal categories capture the circumstances that form the structure of the studied phenomenon, strategies describe the actions or interactions of people in response to the phenomenon, and consequential categories represent the outcomes of the actions or interactions. Thus, through axial coding, the 
researchers will be able to answer when, where, why, who, how and with what consequences questions (Charmaz 2006:60-61; Osmer 2008:52; Saldaña 2013:220). In Figure 1 an example of Saldaña (2013:220) serves as explanation.

\section{Theoretical (selective) coding}

It is the process to select the theoretical code or core category that functions like an umbrella that covers all codes and categories. It relates to all categories and subcategories. It addresses the how and why questions to explain the phenomena. However, this is not necessary for every qualitative study (Saldaña 2013:223-224; Schurink et al. 2012:413). In Figure 2 another example of Saldaña (2013:225) sheds light on this aspect of coding.

The central or core category of the study is DISCRIMINATING. Adolescents discriminate when they choose their friends. They discriminate through a process of accepting and excepting. Adolescents socially discriminate in their choice of friendships (Saldaña 2013:225-226).

\section{Approaches to data analysis in qualitative research}

Poggenpoel (1998:338) mentions five approaches to data analysis in qualitative research, namely the constant comparative method of Lincoln and Guma, the approach of Huberman and Miles, Morse and Field's approach, the method of Marshall and Rossman and Tesch's approach. Creswell's (2014:196-200) data analysis process will also be discussed as a sixth possible approach.

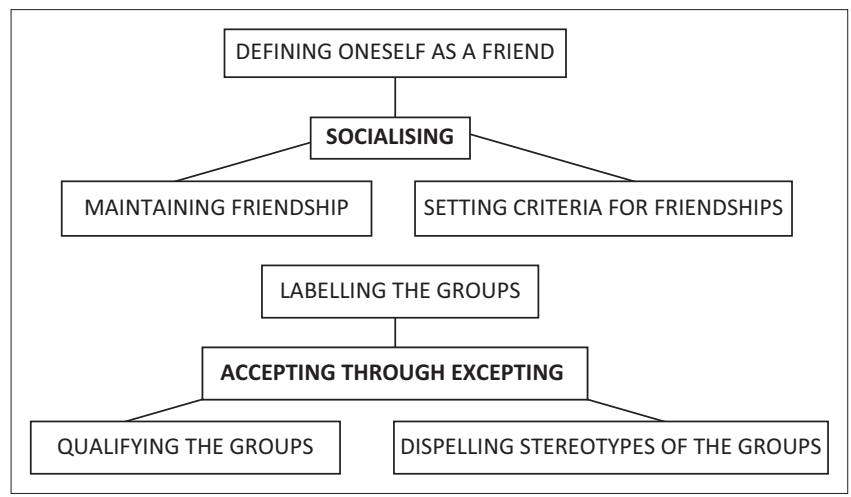

Source: Saldaña, J., 2013, The coding manual for qualitative researchers, 2nd edn., Sage, London

FIGURE 1: An example of axial coding.

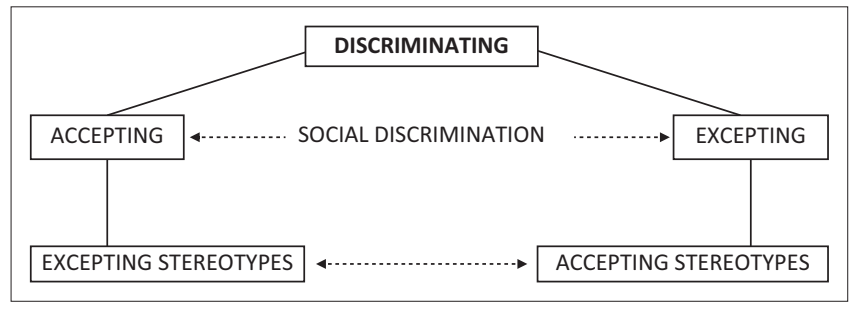

Source: Saldaña, J., 2013, The coding manual for qualitative researchers, 2nd edn., Sage London

FIGURE 2: An example of theoretical coding.

\section{Constant comparative method of Lincoln and Guma}

This method of processing data consists of four stages and Poggenpoel (1998:339-340) explains them as follows.

\section{Comparing units applicable to each category}

The researchers identify units of information that can stand separately and code these units. If there are units that are related because they address the same content, the researchers put them together in provisional categories. By comparing the units within each category, researchers determine the theoretical properties of the category. There will be descriptive and explanatory categories.

\section{Integrating categories and their properties}

Next, the researchers compare the units in the same category with the properties of the category. In this way, the category properties become explicit, which is necessary to integrate categories.

\section{Delimiting the construction}

As the integration of categories progress, the number of categories becomes less and the categories become saturated.

\section{Writing the construction}

The researchers write the reports and present the results to the participants to verify the validity of the results.

\section{Approach of Huberman and Miles}

Poggenpoel (1998:340) states that this approach of data analysis consists of three processes:

\section{Data reduction}

Once the data is available, data summaries, coding, finding themes, clustering and writing stories are ways to select and condense data.

\section{Data display}

The data is then organised to facilitate the thinking about the meaning of the data.

\section{Conclusion drawing and verification}

Now the researchers make interpretations and draw meaning from the data by comparing contrasts, noting patterns and themes, clustering, using metaphors, using triangulation, looking for negative cases and check the results with the participants.

\section{Morse and Field's approach}

In this approach to data analysis, says Poggenpoel (1998:341342), the light falls on four cognitive processes.

\section{Comprehending}

Coding is a central process, because it helps the researchers to sort the data, but also to understand the underlying meanings in the text. 


\section{Synthesising}

This involves the analysis of categories by looking for commonalities.

\section{Theorising}

Theorising is to select and fit alternative models to the data in order to construct alternative explanations of the data. The process continues until the researchers find the best explanation for the data.

\section{Recontextualising}

It is the establishment of the emerging theory from the particular research so that the theory is applicable to other settings and populations.

\section{Approach of Marshall and Rossman}

This approach to data analysis has five stages and in each of the stages, the researchers reduce the data to manageable parts. Each stage also involves interpretations as the researchers bring meaning to the data (Poggenpoel 1998:342-343).

\section{Organising the data}

The first step is that the researchers should read and reread the data in order to familiarise themselves with the content of the data. In the process, they can list the data on note cards, do minor editing of the data and organise voluminous data.

\section{Generating categories, themes and patterns}

The researchers need to identify prominent themes, recurring ideas and patterns of belief that link people and settings together. These become the categories. This is inductive analysis, because the categories emerge from the data.

\section{Testing emergent hypotheses}

By looking at the categories from the data and the patterns between them, it is possible that hypotheses can arise. It is important to test these against the existing data.

\section{Searching for alternative explanations}

The researchers should also look for alternative explanations, describe it and motivate why it is possible.

\section{Writing the report}

This is part of the analytic process, because as the researchers choose particular words to summarise and reflect the data, they are busy with interpretinge the process by giving shape, form and meaning to the data.

\section{Eight steps of Tesch}

Tesch (1992:142-145) provides detailed guidelines to develop an organising system for unstructured qualitative data:

- Get a sense of the whole by reading carefully through all the data. This gives the researchers the necessary background information. If something comes to mind about the data, the researchers should write these ideas down.
- The researchers start with one document and whilst going through it, ask themselves 'What is this about?' The question does not refer to the content of the document, but to the topic. Write these topics in the margin of the document.

- After completing this procedure for several documents, the researchers make a list of all the topics, one column per data document, placing all the columns on the same sheet. They need to compare all the topics and group similar topics together. Write these groups in columns, perhaps with headings that represent the major topics, the unique topics and leftovers.

- Abbreviate these topics as codes. With this list of codes, the researchers go back to the data and write the codes next to the appropriate segments of the text. Be open for new categories and codes that may emerge. If any ideas about the data come to mind, the researchers should write it down in their notes (analytic memos).

- Find the most descriptive words for the topics, which have begun to turn into categories. Try to reduce the categories by grouping together those that relate to each other. Try to look for subcategories. A 'normal' number of categories is between 20 and 50. This is the organising system for the data.

- Make a final decision on the abbreviation of each category and alphabetise the codes to ensure that no duplication occurs. The researchers should remember that categories have fuzzy boundaries and a segment of data can fit in two or three categories.

- Put the data belonging to each category together and perform a preliminary analysis, looking at all the material in one category at a time. The focus is now on the content of each category. During this process, keep the research question in mind in order to discard irrelevant data.

- If necessary, recode the existing data. The organising system may help the researchers to give structure to their research reports.

\section{Creswell's approach}

Although Creswell (2014:196-200) presents his approach as a linear, hierarchical process, he states categorically that the six steps are interrelated and do not necessarily follow in the order they are given.

\section{Organise and prepare the data for analysis}

This refers to the transcribing of the interviews and the sorting and arranging of the data if different sources of information are used.

\section{Read through all the data}

By doing this, the researchers get a general sense of the information and possibly its overall meaning. Perhaps the researchers want to write down general ideas about the data.

\section{Coding of the data}

It is the process of organising the data into chunks of information and writing a word that represents a category in the margin. 


\section{Description of the setting or people and categories or themes for analysis}

During the coding process, the researchers give detailed descriptions of the setting or the people involved as well as descriptions of the categories or themes for analysis.

\section{Present the results of the analysis}

This is often done in a narrative passage to convey the findings of the analysis. It may include a chronology of events, a detailed discussion of several themes or a discussion of interconnecting themes.

\section{Interpretation of the results of the analysis}

The aim is to answer the following question: 'What were the lessons learned?'

\section{Proposed model for coding and data analysis in practical theological studies}

After studying the coding techniques as set out by Saldaña and some of the existing approaches to data analysis mentioned above, I propose the following model for coding and data analysis during qualitative empirical research in practical theological studies. I trust that students and practical theologians can implement it fruitfully in their postgraduate studies and research articles. The model consists of five phases:

\section{Phase 1: Preparing the data}

The researchers need to decide whether they are going to do a verbatim transcription of the data versus just giving the essence (gist) of what the participant conveyed in the interview. Then the researchers type the data on two-thirds of the page, leaving a margin on the right. Whenever a new topic starts, the researchers start a new paragraph. During this process of preparing the data, the researchers may already do some precoding by circling, highlighting or underlining significant words or sentences. It is a good idea to start early with the process and not wait until all the data has been gathered.

\section{Phase 2: Coding}

The researchers can code the following: activities and behaviour, objectives, events, strategies and tactics, present situations, meanings, participation, relationships and interactions, conditions and constraints, consequences, assumptions, settings and the researcher's own reflections. These may come from the analytical memos that the researchers write continuously.

During the first cycle of coding, in order to split the data, the researchers do initial coding by using in vivo coding (the researchers put the exact word or phrase of the participant in inverted commas), and process coding (the researchers use gerunds to portray action). In the second cycle, the researchers reassemble the data by using focused coding to develop categories.

\section{Phase 3: Member checking}

In order to ensure the quality of the qualitative empirical research, the researchers pursue to guarantee the credibility of the research. In other words, the researchers want to ascertain that they portray accurately what the participants conveyed. One way to increase credibility is to make use of member checking. After the coding process, the researchers can ask the participants to verify the validity of the content of their specific data as well as the results of the coding process. The researchers need to address issues indicated by the participant(s).

\section{Phase 4: Interpreting results}

The researchers look at one category at a time and focus on the content of each category. In order to interpret the results and draw meaning from it, the researchers can compare contrasts, note patterns and themes, they can cluster, use metaphors and even look for negative cases. I agree with Osmer (2008:4) that the researchers draw on theories in the literature in an attempt to explain why the patterns in the results occurred.

\section{Phase 5: Presenting the data}

The data analysis process culminates in the researchers' written reports wherein they discuss the findings of the empirical research and give their conclusions.

\section{Conclusion}

An investigation into recent research outputs by practical theologians at the NWU, in all sub-disciplines of Practical Theology, revealed that the qualitative empirical research skills of lecturers and postgraduate students need further development, especially in the area of coding and data analysis. I proposed a model for coding and data analysis in practical theological studies.

\section{Acknowledgements Competing interests}

The author declares that she has no financial or personal relationship(s) that may have inappropriately influenced her in writing this article.

\section{References}

Bowker, J., 1999, The Oxford dictionary of world religions, Oxford University Press, Oxford.

Burger, C., 1991, Praktiese Teologie in Suid-Afrika: 'n ondersoek na die denke oor sekere voorvrae van die vak, RGN, Pretoria.

Charmaz, K., 2006, Constructing grounded theory: A practical guide through qualitative analysis, Sage, Thousand Oaks.

Creswell, J.W., 2014, Research design: Qualitative, quantitative and mixed methods approaches, 4th edn., Sage, Thousand Oaks.

De Klerk, B.J. \& De Wet, F.W., 2013, Met die oog op God: Voorveronderstellings van die reformatoriese invalshoek op Praktiese Teologie, Potchefstroomse Teologiese Publikasies, Potchefstroom.

Dingemans, G.D.J., 1996, 'Practical Theology in the academy: A contemporary overview', The Journal of Religion 76(1), 82-96. http://dx.doi.org/10.1086/489737

Dreyer, J.S., 2012, 'South Africa', in B.J. Miller-McLemore (ed.), The Wiley-Blackwell companion to Practical Theology, pp. 505-514, Wiley-Blackwell, Malden.

Dreyer, J.S., 2015, Academic biography, viewed 1 August 2015, from http://www. unisa.ac.za/Default.asp?Cmd=ViewContent\&ContentID=22647 
Engler, S., 2014, 'Grounded theory', in M. Stausberg \& S. Engler (eds.), The Routledge handbook of research methods in the study of religion, pp. 256-274, Routledge, New York.

Horton, M., 2014, Semper reformanda, viewed 11 April 2014, from http://www. semperreformanda.com/men-of-god/semper-reformanda-by-michael-horton/

Lotter, G.A., 2001, 'The "reformation" of counselling', In die Skriflig 35(2), 319-331.

Lotter, G.A., 2007, 'Pastorale Teologie: Voëlvlug en (voorlopige) landing', Inaugurele rede, Noordwes-Universiteit, Potchefstroom, 29 Oktober 2004.

McClure, B., 2012, 'Pastoral care', in B.J. Miller-McLemore (ed.), The Wiley-Blackwell companion to Practical Theology, pp. 269-278, Wiley-Blackwell, Malden.

Miller-McLemore, B.J., 2012, 'The contributions of practical theology', in B.J. MillerMcLemore (ed.), The Wiley-Blackwell companion to Practical Theology, pp. 1-20, Wiley-Blackwell, Malden.

Osmer, R.R., 2008, Practical Theology: An introduction, Eerdmans, Grand Rapids.

Pieterse, H.J.C., 1991, 'Duitsland', in C. Burger (ed.), Praktiese Teologie in Suid-Afrika: 'n ondersoek na die denke oor sekere voorvrae van die vak, pp. 5-12, RGN, Pretoria.

Pieterse, H.J.C., 2010, 'Grounded theory approach in sermon analysis of sermons on poverty and directed at the poor as listeners', Acta Theologica 30(2), 113-129. http://dx.doi.org/10.4314/actat.v30i2.67265

Pieterse, H.J.C., 2011, 'An open coding analytical model of sermons on poverty with Matthew 25:31-46 as sermon text', Acta Theologica 31(1), 95-112. http://dx.doi. org/10.4314/actat.v31i1.6

Pieterse, H.J.C., 2012, 'A grounded theory approach to the analysis of sermons on poverty: Congregational projects as social capital', Verbum et Ecclesia 33(1), Art. \#689, 7 pages. http://dx.doi.org/10.4102/ve.v33i1.689
Pieterse, H.J.C., 2013, 'An emerging grounded theory for preaching on poverty in South Africa with Matthew 25:31-46 as sermon text', Acta Theologica 33(1), 175-195. http://dx.doi.org/10.4314/actat.v33i1.9

Pieterse, H.J.C., 2015, Prof HJC Pieterse, viewed 1 August 2015, from http://www. unisa.ac.za/Default.asp?Cmd=ViewContent\&ContentID=95282

Poggenpoel, M., 1998, 'Data analysis in qualitative research', in A.S. de Vos, H. Strydom, C.B. Fouché, M. Poggenpoel, E. Schurink, \& W. Schurink (eds.), Research at grass roots: A primer for the caring professions, pp. 334-353, Van Schaik, Pretoria.

Saldaña, J., 2013, The coding manual for qualitative researchers, 2nd edn., Sage, London.

Schurink, W., Fouché, C.B. \& De Vos, A.S., 2012, 'Qualitative data analysis and interpretations', in A.S. de Vos, H. Strydom, C.B. Fouché \& C.S.L. Delport (eds.), Research at grass roots: For the social sciences and human service professions, pp. 397-423, Van Schaik, Pretoria.

Smith, K. \& Davies, J, 2010, 'Qualitative data analysis', in L. Dahlberg \& C. McCais (eds.), Practical researcher and evaluation: A start-to finish guide for practitioners, pp. 145-158, Sage, London.

Tesch, R., 1992, Qualitative research: Analysis types and software tools, Falmer, New York.

Troxel, A.C., 2006, Reformanda, viewed 11 April 2014, from http://www. reformation21.org/counterpoints/post-32.php

Van der Ven, J., 1993, Practical Theology: An empirical approach, Kok Pharos, Kampen.

Vorster, J.M., 2010, 'An ecclesiological model for the ministry of reconciliation in a socio-political context', In die Skriflig 44(2), 429-454. http://dx.doi.org/10.4102/ ids.v44i2.154

Wolters, A.M., 1992, Die skepping herwin: Bybelse grondslae vir 'n reformatoriese lewensbeskouing, PU vir $\mathrm{CHO}$, Potchefstroom. 